\section{A Longitudinal Study on the Chemical Knowledge of Prospective University Students}

\author{
Nele Milsch iD \\ Georg August University Göttingen \\ nmilsch@gwdg.de \\ Thomas Waitz* \\ Georg August University Göttingen \\ twaitz@gwdg.de
}

\section{Abstract}

Many universities face the challenge that high dropout rates (e.g. $30 \%$ in chemistry in Germany) are observed in higher education. Accordingly, the college readiness of prospective students is doubted. In this context this article focuses on the content-specific and cognitive characteristic as part of the college readiness. Within a four year span, we examined the responses from more than 500 prospective students who participated in a content-specific prior knowledge test in chemistry. Overall, we found that contentspecific prior knowledge test and average Abitur grade (final high school grade) remained almost constant. In addition, a low correlation between the content-specific knowledge and the average Abitur grade was found. Finally, only deficits and strengths in individual subject areas of chemistry could be identified throughout the years, which are presented in this article as examples.

\section{Keywords}

college readiness, average Abitur grade, chemical knowledge, cognitive and content-specific characteristics, longitudinal study, prospective students

- Received 20 May 2020 • Revised 30 April 2021 • Accepted 5 May 2021

\section{Introduction}

The development of new techniques in the field of science and technology can provide a valuable contribution to overcome the challenges the society of the 21 st century is facing to. One key to accomplish these problem is the extension of higher education, especially in science, technology, engineering and maths to a more widespread part of our society. This is in agreement with claims of the United Nations, aiming to "[e]nsure inclusive and equitable quality education and promote lifelong learning opportunities for all" (United Nations Economic and Social Council, 2019, p. 10). In order to use the full potential of all people for the welfare of a society, higher education has to be and will be accessible to greater parts of the people, opening new perspectives but also new challenges for universities.
State of the literature

- The college readiness to study included four characteristics: cognitive, content-specific, social and personal.

- The college readiness is criticized in the public and recent educational research as well as the trend to better average Abitur grades.

- Cognitive and content-specific characteristics is part of some scientific studies, but has, to our knowledge, not yet been studied for prospective students in higher education in the field of chemistry.

\section{Contribution of this paper to the literature}

- A low correlation between the content-specific knowledge and the average Abitur grade was found. - Within four years at the university in Göttingen, the content-specific prior knowledge test and average Abitur grade remained steady.

- Only in 3 of 34 tasks in the content-specific prior knowledge test in chemistry a significant difference between the cohorts can be found.

- Deficits and strengths in individual subject areas of chemistry could be identified and used to develop guidelines for intervention measures.

In recent years, the access for example to universities, has been steadily opened. In other words, more and more universities in Europe accept alternative entrance qualifications (Halsey, 1993). Thus, the diversity of students is increasing with regard to the transition to higher education (Halsey, 1993). On the one hand, this favours an inclusive education as mentioned above, whereas on the other hand, due to the enhanced heterogeneity, it gets more difficult to maintain the quality of higher education (Shaker \& Plater, 2016). In this context, terms such as inflation of grades, as well as 'academization mania' (i.e. yearly increasing number of higher education students) towards the future generation are used and a plight of higher education is postulated since lecturers for example have been criticizing that almost a third of the first semester students are actually not ready for university (cf. Conley, 2011; Fokken, 2016; Klein, 2019; Konegen-Grenier, 2002; NidaRümelin, 2014; Wolter \& Kerst, 2015).

\section{Theoretical and Conceptual Framework}

\section{College Readiness}

The smooth transition between high school and higher education remains a crucial step for an academic success (Conley, 2011, 2014). Freshmen must distance themselves from previous experiences of their education path and adjust to the new circumstances. Besides the deepening of content knowledge,

[t]he student-teacher relationship changes dramatically, as do expectations for engagement, independent work, motivation, and intellectual development. All this occurs while young people are also grappling with significant independence from 
their families and with the transition from childhood to adulthood. It is not surprising that moving from high school to college is one of the most difficult transitions that many people experience during their entire lives. (Conley, 2011, p. 2)

Therefore, it is essential that the prospective students are ready for college and are able to apply their acquired knowledge from school. One of the most commonly used concepts of a "College Readiness" in an international context is defined by Conley (Conley, 2014). It distinguishes between the four different areas, which are interdependent:

The four keys include thinking skills (key cognitive strategies), attitudes toward and understanding of the structure of the content being presented (key content knowledge), ownership of learning in the form of self-regulatory behaviours along with specific methods for being an effective learner (key learning skills and techniques), and contextual knowledge required to select a college, apply successfully, cope with financial demands, understand the culture of college, and be aware of how the role of college student is different from that of high school student (key transition knowledge and skills). (Conley \& French, 2014, p. 1019)

In Germany, there are various concepts regarding the college readiness or the academic success (cf. Bosse, Schultes, \& Trautwein, 2013; Konegen-Grenier, 2002). Thus, this paper will focus on the college readiness as part of the academic success according to Sorge et al (2016). The mentioned authors presented a modified model (based on: Heldmann, 1984; Kazemzadeh, Minks, \& Nigmann, 1987; Konegen-Grenier, 2002; Thiel, Veit, Blüthmann, Lepa, \& Ficzko, 2008) which they have already successfully applied to the German higher education system in the subject physics. This concept contains three important aspects for an academic success which are the (I) study capacity, (II) study conditions/general living conditions and (III) behaviour of studying. Furthermore, the study capacity includes four characteristics: cognitive, contentspecific, social and personal. (Sorge et al., 2016) The authors have identified cognitive and content-specific characteristics as the most important predictors for an academic success, which we primarily investigate in our study.

When comparing these two basic literature sources, similarities can be found between the four key areas (including 42 components) of College Readiness by Conley and the three aspects of Sorge et al. for academic success (see Figure 1). For example, Conely's 'key cognitive strategies', summarized under the headline 'Think', are defined with keywords such as: 'problem formulation', 'research', 'interpretation' with the subcategorie 'Analyze' (Conley, 2014). The author Konegen-Grenier describes the cognitive characteristic with similar keywords such as 'ability to analyze' and 'ability to abstract' which have been considered in the model of Sorge et al. (Konegen-Grenier, 2002; Sorge et al., 2016). For Konegen-Grenier (2002), the content-specific characteristic is provided by the knowledge of the individual subjects (e.g. English, mathematics,
German). Conley $(2011,2014)$ defines 'key content knowledge' under the headline 'Know' and considers both 'overarching academic skills' and 'core academic subjects knowledge and skills' which he describes as the knowledge required for an individual subject. Both concepts argue that the 'key cognitive strategies' / 'key content knowledge' by Conley or respectively 'cognitive'/ 'content-specific' characteristics by Sorge et al. can be analysed by standardised assessments and grades (Conley, 2014; Sorge et al., 2016). In America, for example, the content knowledge/cognitive skills can be determined using the SAT or ACT (Conley, 2014). In Germany, the cognitive and content-specific characteristics can be described using the average Abitur grade / individual grades of the subject (Sorge et al., 2016).

The other two keys (key learning skills \& techniques and key transition knowledge \& skills) will not be described in the following, as the focus of this study lies on the mentioned key area (cf. Conley, 2014; Sorge et al., 2016).

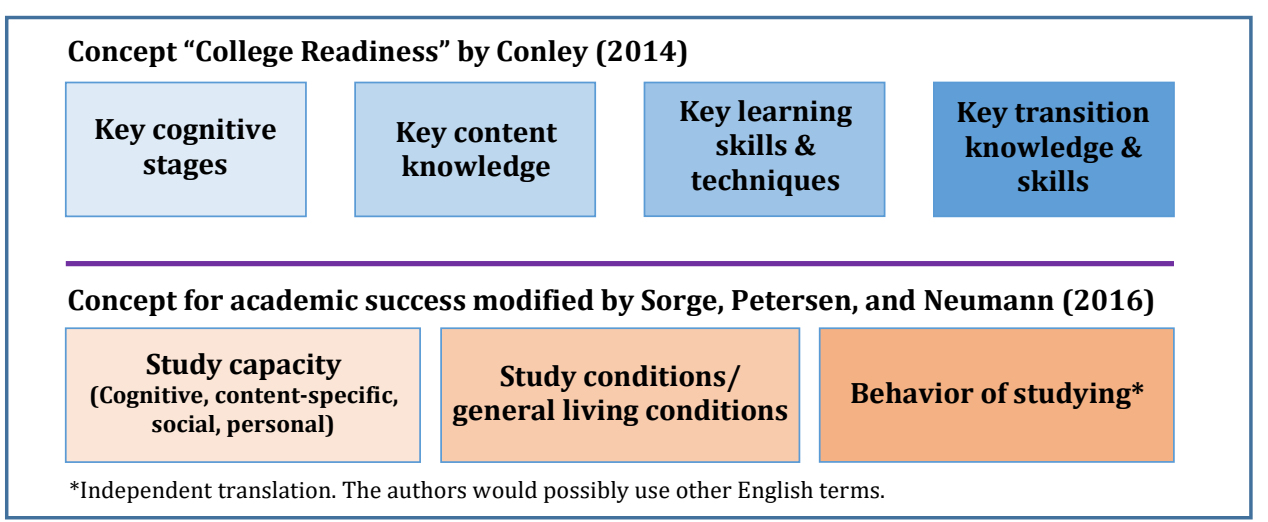

Figure 1. Comparison of the two concepts for college readiness/academic success in the literature.

Even though a lot of different factors are defining a college-ready student, the entrance qualification for higher education usually depends only on the grades achieved during final exams (e.g. Halsey, 1993; McGrath et al., 2014). However, also the rate of dropouts indicates that just relaying on this form of entrance criteria should be critically questioned. For example, the nationwide dropout rate for chemistry students in Germany increased dramatically within 10 years (2002-2012) from 23\% to 45\% (Heublein et al., 2002; Heublein \& Schmelzer, 2018).

\section{Current situation in Germany}

In Germany, the entrance qualification for higher education is usually given by the Abitur. The average Abitur grade is formed by several grades over two years of attendance at an upper secondary school plus the final exams, whereby not only content-specific knowledge but also application-related skills are considered when awarding grades. According to Sorge et al., the 
Abitur displays the cognitive characteristic of a freshman. (Trapmann et al., 2007) The contentspecific characteristic can be described by the individual grades in a particular subject or by a corresponding knowledge test.

According to a meta-analysis by Trapmann et al. (2007), the school grades seem to be the strongest predictor for academic success (for Germany $\rho=.53$, for STEM $\rho=.58$, corrected according to the original authors). In chemistry, Freyer also identified the average Abitur grade $(\beta=-.415)$ and prior knowledge $(\beta=.208)$ as significant factors for academic success and, above all, for the further accumulation of knowledge (Freyer, 2013). It should be noted that prediction based on the Abitur grade is primarily concerned with learning performance, but is not suitable for predicting practical skills, such as laboratory skills (Schuler, 2006).

Nevertheless, the average Abitur grade is often criticized for its subjectivity, because they are highly related to a state, school, and even teacher (Trapmann et al., 2007). Moreover, looking at the development of the average Abitur grade in Germany, particularly in the state of Lower Saxony, it becomes clear why statements about inflation of grades are made. Over the period 2006 to 2018, the average Abitur grade in Lower Saxony shows a trend towards better entrance qualifications (see Figure 2). Also, in the US, the grade point average increased within fifteen years (1990-2005) from 2.68 to 2.98 (Shettle et al., 2007). However, as Ziomek and Svec stated the ability of students did not improve, which supports the hypothesis of a grade inflation (Ziomek \& Svec, 1995).

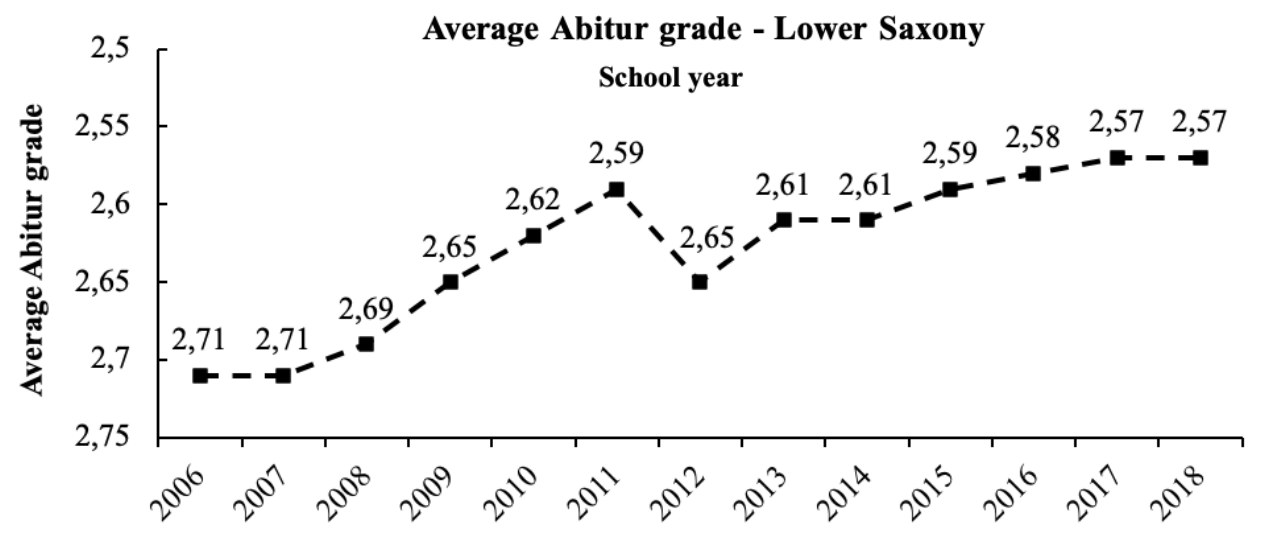

Figure 2. Development of the average Abitur grade throughout Lower Saxony over the school years 2006 to 2018. A lower number indicates a better average. In Germany there are grades from 1 (best) to 6 (worst). Taken from the open accessible source: Sekretariat der Ständigen Konferenz der Kultusminister der Länder in der Bundesrepublik Deutschland, various years, 2006-2018.
In this context, the question arises to what extent the better grades also lead to a more effective preparation for higher education. For this purpose, we will mainly investigate to which extent the content-specific prior knowledge as an essential part of the college readiness has changed in recent years among prospective chemistry students at the Georg-August-University in Göttingen, Germany. These findings might be useful for a smooth transition from secondary school to higher education to increase the academic success worldwide.

\section{Motivation}

A review of the current literature shows that there are hardly any trend studies on the chemical knowledge of prospective students in chemistry courses. Additionally, due to the debate of the college-ready student, the present study will focus on the content-specific characteristics. The aim is to examine whether the content-specific characteristics as part of the college readiness changes over the considered period of time, assuming that the average Abitur grade remains constant over four years. From this finding, statements on the quality of prior knowledge need to be derived in order to evaluate whether the criticism of university teachers about a lack of prior knowledge is justified (Konegen-Grenier, 2002). Hence, the data collected at the Georg-August-University Göttingen in a content-specific prior knowledge test were analysed with regard to the following questions:

Q1) What is the relation and distribution of the total score from the content-specific prior knowledge test in chemistry to the average Abitur grade (independent of the investigation period)?

Q2) What developments can be observed in the chemical knowledge of prospective students in Göttingen over the last four years, while the average Abitur grade has remained almost the same?

Q3) Are there differences between the cohorts in content knowledge with regard to specific basic chemical topics and concepts?

Q4) Are there general deficits and strengths in basic concepts in chemistry?

\section{Method}

\section{Survey instrument}

For the survey, a paper-pencil study has been conducted at the Georg-August-University of Göttingen over the last four years. The questionnaire, which we used for our study, was designed on the basis of the content knowledge from secondary level I and II of all curricula of the federal states as well as on the survey by Busker (2010) and it's adaptation by Wolf (2018). For further application examples see also Busker, Klostermann, Herzog, Huber, \& Parchmann, 2011; Busker, Wickleder, \& Parchmann, 2010. Furthermore, the test was supplemented by interviews with teachers of the Faculty of Chemistry in Göttingen to ensure that knowledge that is considered essential for studying in chemistry is included in this test (Wolf, 2018). 
The questionnaire contains 34 scientific tasks focusing on the basic concept of 'matter and particles'. Our focus on this concept is given by its key role for understanding scientific perception of our environment (cf. Eilks, 2007; Eilks \& Möllering, 2001). Overall, the test sheet consists of both open and closed questions. For the closed questions, a multiple-choice format was selected in which one or more correct answer options were to be ticked. In addition, the test sheet required personal information and aspects of the average Abitur grade. Furthermore, the external conditions (such as instruction, time of day, room) were kept constant during the test survey.

\section{Sample}

The sample consists of 530 prospective Bachelor students (55.3\% male, $42.5 \%$ female, $2.2 \%$ not specified) studying at Georg-August-Universität Göttingen between 2015 to 2018 and thus represents a partial survey. The education background of the respondents shows diverse difficulty levels (e.g. basic level, advanced level) during school education in the subject chemistry. Prospective bachelor students in the fields of chemistry, such as chemistry major (B.Sc.), chemistry with teaching profession (B.A.), materials science (B.Sc.), biochemistry (B.Sc.), biology (B.Sc.) as well as a few other natural science programmes (B.Sc.) were surveyed. The exact distribution is shown in Table 1.

Table 1. List of the respondents' distribution by degree programme over the survey year.*

\begin{tabular}{|c|c|c|c|c|c|c|c|}
\hline & \multicolumn{7}{|c|}{ Degree Programme } \\
\hline & 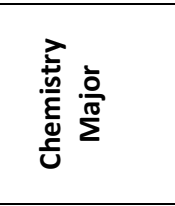 & 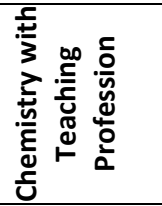 & 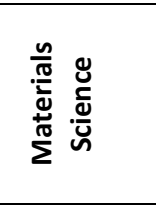 & 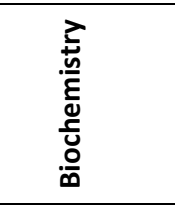 & $\frac{30}{\frac{0}{\circ}}$ & 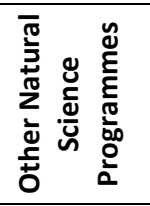 & $\begin{array}{l}\overline{\bar{\sigma}} \\
\text { है } \\
z\end{array}$ \\
\hline 2015 & $56.1 \%(88)$ & $12.1 \%(19)$ & $10.8 \%$ (17) & $19.1 \%(30)$ & $1.3 \%(2)$ & $0.6 \%(1)$ & 157 \\
\hline \multirow{3}{*}{ 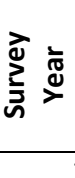 } & $57.0 \%$ (69) & $9.1 \%(11)$ & $9.9 \%(12)$ & $24.0 \%(29)$ & $0.0 \%(0)$ & $0.0 \%(0)$ & 121 \\
\hline & $52.7 \%(68)$ & $9.3 \%(12)$ & $0.0 \%(0)$ & $38.0 \%(49)$ & $0.0 \%(0)$ & $0.0 \%(0)$ & 129 \\
\hline & $55.1 \%(65)$ & $16.1 \%(19)$ & $0.0 \%(0)$ & $28.0 \%(33)$ & $0.0 \%(0)$ & $0.8 \%(1)$ & 118 \\
\hline Total & $55.2 \%(290)$ & $11.6 \%$ (61) & $5.5 \%(29)$ & $26.9 \%$ (141) & $0.4 \%(2)$ & $0.4 \%(2)$ & 525 \\
\hline
\end{tabular}

*5 respondents made no statement about their degree programme.

\section{Data analysis}

First, it has been verified whether the data is normally distributed or not (test according to Kolmogorov-Smirnov), in order to be able to carry out appropriate comparisons of the contentspecific prior knowledge test in chemistry and the average Abitur grade for the years (H-test according to Kruskal and Wallis). Furthermore, a correlation analysis is carried out according to using Spearman's Rho test to compare the average Abitur grade and the content-specific prior knowledge test. Additionally, a chi-square test is used to compare the single tasks over the years.

\section{Results \& Discussion}

\section{Relation and distribution of the total score from the content-specific prior} knowledge test in chemistry to the average Abitur grade

Q1) What is the relation and distribution of the total score from the content-specific prior knowledge test in chemistry to the average Abitur grade (independent of the investigation period)?

This research question aims to clarify whether or not the score achieved in the content-specific prior knowledge test depends on the average Abitur grade. In addition, the scattering of score by a value of the average Abitur grade needs to be investigated.

The analysis of the correlation between the average Abitur grade and performance in the contentspecific prior knowledge test across all test results shows a low correlation, where a better A-level score is followed by a better performance in the content-specific prior knowledge test (Test Spearman-Rho: $\mathrm{r}=-.354, \rho=.000, \mathrm{~N}=513$ ).

A linear correlation between the content-specific prior knowledge test and the average Abitur grade shows a coefficient of determination R2 of 0.135 , which means that only $13.5 \%$ of the performance of the total test score can be attributed to the average Abitur grade. The single data points over all years and their distribution when comparing the two variables can be seen in Figure 3.

It can be deduced that the correlation between the average Abitur grade and the score in the content-specific knowledge test is very low. A high scattering of scores of the content-specific knowledge test around a value of the average Abitur grade can be determined. This means that a person with a good average Abitur grade does not necessarily perform well in the content-specific knowledge test. For example, the average Abitur grade of 1.8 shows a scatter of 7 to 28 points, with most data points being worse than the A-level average of 1.9 and 2.0. Accordingly, it can be concluded that the content-specific knowledge test represents a good objective view of the content knowledge and shows a high degree of selectivity. 
Scatter plot of total score (content-specific knowledge test) to average Abitur grade

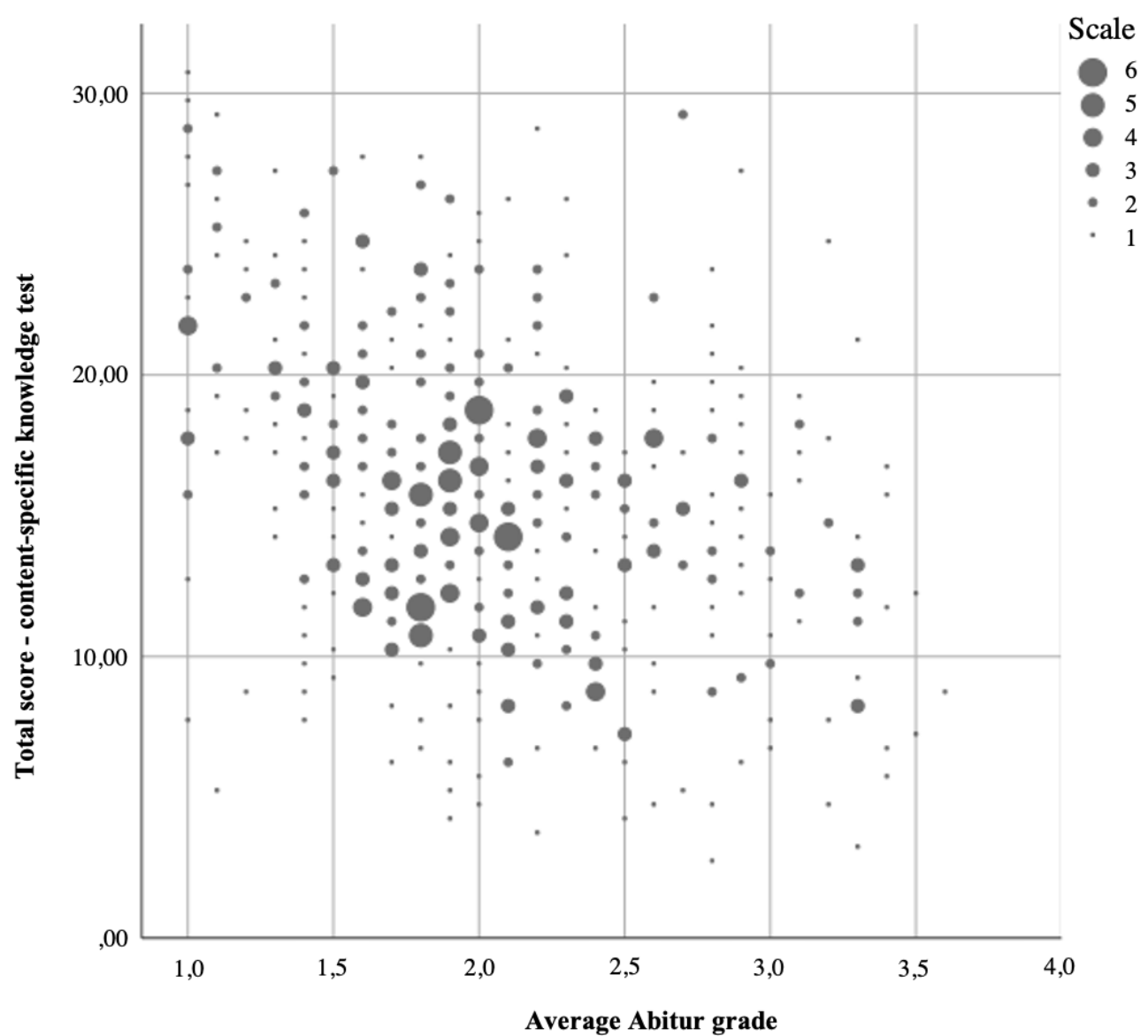

Figure 3. Scatter plot of the single data points from the total score of the content-specific knowledge test to the average Abitur grade. The scale shows the number of identical data points.

Development of the chemical knowledge with an almost constant A-level average

Q2) What developments can be observed in the chemical knowledge of prospective students in Göttingen over the last four years, while the average Abitur grade has remained almost the same?

The average Abitur grade didn't change or increase statistically significant during the last four years among the examined prospective students in fields where chemistry is relevant for the degree programme at the University of Göttingen - these differences or improvements range between 2.00 and 2.09 (see Table 2). Considering the generally increasing average Abitur grade in recent years (see 2.2 Current situation in Germany), the question arises if and to what extent changes in chemical knowledge can be observed while the average Abitur grade remains the same.

Table 2. Average Abitur grade in relation to the year.

\begin{tabular}{ccc}
\hline Year & $\begin{array}{c}\text { Number of } \\
\text { Respondents }\end{array}$ & $\begin{array}{c}\text { Average Abitur } \\
\text { Grade }\end{array}$ \\
\hline 2015 & 153 & 2.09 \\
2016 & 121 & 2.06 \\
2017 & 127 & 2.00 \\
2018 & 112 & 2.06 \\
\hline
\end{tabular}

Figure 4 shows the results of the content-specific prior knowledge test over the years. Obviously, the mean values and scatter hardly differ between the cohorts; overall, on average about half of the total points (a total of 34 possible points) are achieved in the content-specific prior knowledge test. In the statistical analysis of the total score of the content-specific prior knowledge test's results (Kruskal-Wallis H, $\rho=.012$ ) the 2017 cohort is the only one to show significant differences from the other cohorts (U-test, $\rho$-values see Figure 4). With the exception of the 2017 cohort, it can therefore be stated that, with the same average Abitur grade, there are no differences in the overall score of the chemical knowledge tested over the last four years. This means that almost no differences between the cohorts can be identified with regard to the college readiness based on the content-specific characteristics as a predictor. The extent to which this finding is due to a subject-specific phenomenon, to regional peculiarities or to insufficient differentiation of the test cannot be clarified due to the lack of comparative data.

\section{Development of individual chemical questions over the years}

Q3) Are there differences between the cohorts in content knowledge with regard to specific basic chemical topics and concepts?

In total, 10 out of 34 tasks were correctly solved by more than $70 \%$ of participants. On the other hand, 8 tasks were solved with a correctness of less than $30 \%$.

If the single tasks are analysed over the years using the Chi-square test, a deviation of the observed frequencies from the estimated expected frequencies can be found for only three tasks. A correlation according to Cramer's V test in the range of very low $(0.0<\mathrm{r}<=0.2)$ and low $(0.2<$ $\mathrm{r}<=0.5$ ) can be founded (see Table 3). 
Total score (content-specific knowledge test) from year to year

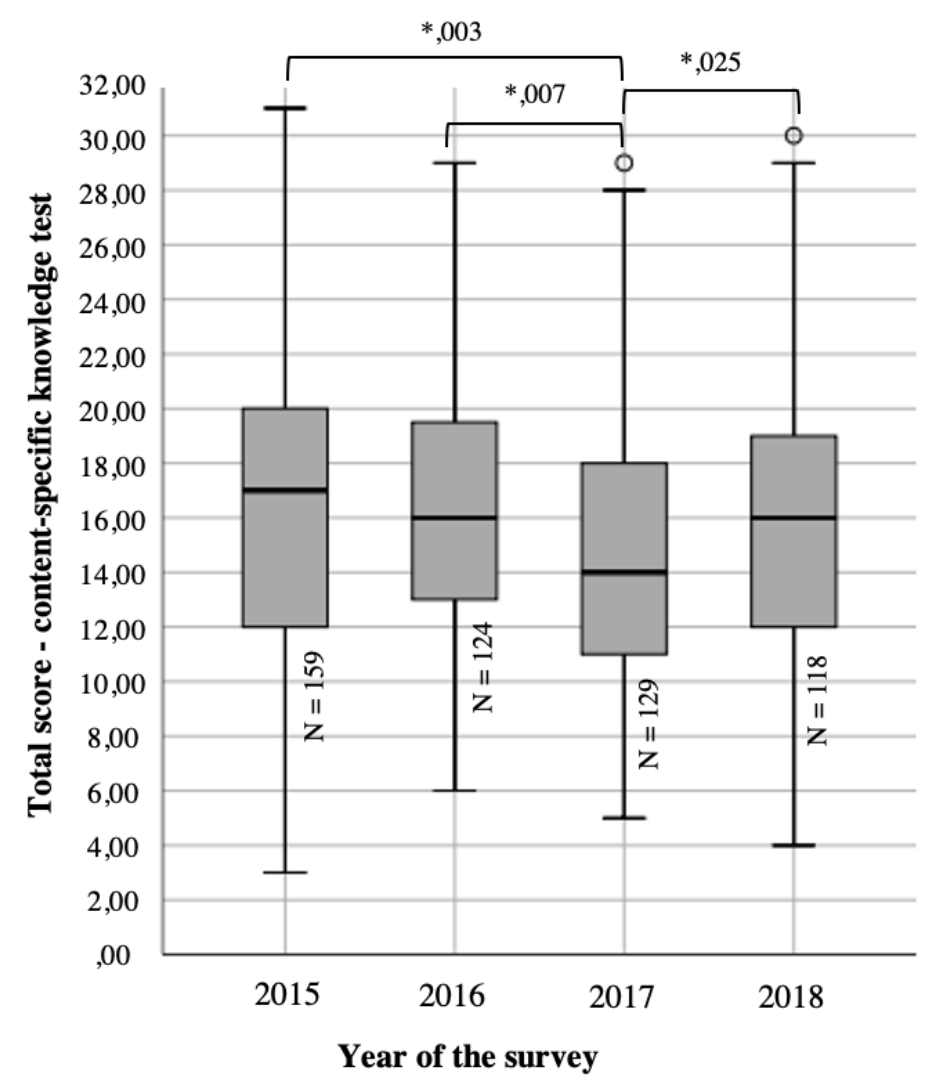

*Asymptotic significance (2-tailed)

Figure 4. Total score of the content-specific prior knowledge test for the years 2015 to 2018 . The UTest shows that the total score of the content-specific prior knowledge test from the year 2017 differs significantly from the other years.

Table 3. Listing of significant results of the single tasks in comparison to the years by analysis of Chisquare according to Pearson and indication of the Cramer's V association measure.

\begin{tabular}{lll}
\hline Task & $\begin{array}{l}\text { Chi-square according to Pearson/ } \\
\text { Asymptotic significance (2-sided) }\end{array}$ & Cramer's V \\
\hline Element/Compound & .042 & $.125(\rho=.042)$ \\
Halogens & .000 & $.209(\rho=.000)$ \\
Stereoisomerism & .001 & $.215(\rho=.001)$ \\
\hline
\end{tabular}

Comparing the distribution of the individual years' response behaviour via bar diagram, one year in the task differentiation between "element/compound" (year 2016 increased correctness) and in the "stereoisomerism" (year 2018 increased correctness) significantly differs compared to the other years. The task "Halogens" (concrete task can be seen in Figure 7) is the only one for which the response behaviour is very diverse from year to year (see Figure 5). The underlying reasons cannot be explained with the present study.

\section{Clustered bar diagram of task "halogens" from year to year}

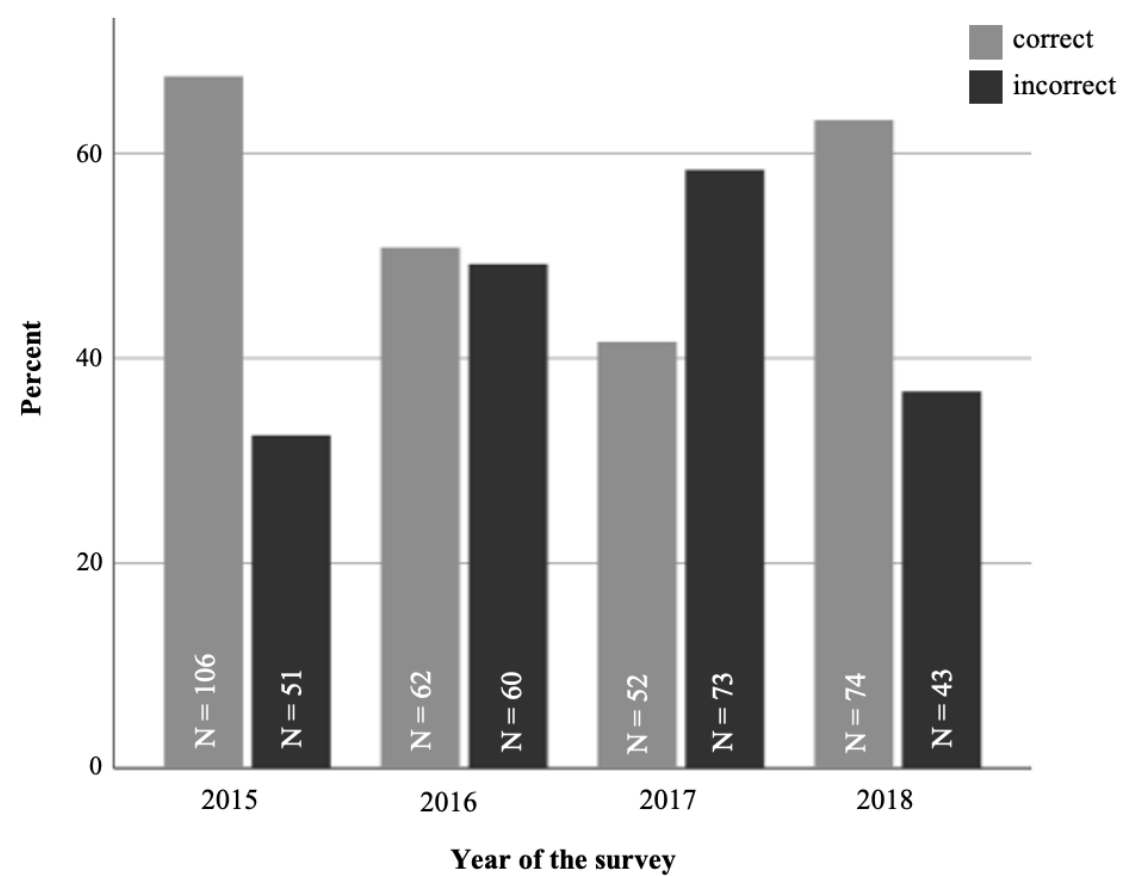

Figure 5. Clustered bar diagram on the correct or incorrect answers of the task "halogens" from year to year.

Selected test results for the general classification of chemical knowledge Q4) Are there general deficits and strengths in basic concepts in chemistry?

In the following, exemplary test questions and the corresponding response behaviour are shown (see Table 4). Although there were no significant changes in these tasks between years, they nevertheless reveal in which topics prospective students have a well-founded knowledge as well as a lack thereof. 
Table 4. Four exemplary tasks out of thirty-four. Overview of validity and response behaviour.

\begin{tabular}{llllll}
\hline Task & $\mathbf{N}_{(\text {Valid) }}$ & $\mathbf{N}_{\text {(Missing) }}$ & Valid [\%] & Correct [\%] & Incorrect [\%] \\
\hline Shell Model & 527 & 3 & 99.4 & 93.0 & 7.0 \\
Metals & 525 & 5 & 99.1 & 68.6 & 31.4 \\
Halogens & 521 & 9 & 98.3 & 56.4 & 43.6 \\
Lewis Structure & 485 & 45 & 91.5 & 15.5 & 84.5 \\
\hline
\end{tabular}

As the first example, the task for the shell model is presented. In this task the students have to choose the correct answer from a multiple-choice question (see Figure 6).

\section{A sodium atom (see figure) forms a single positively charged cation.}

How can this be explained using the shell model?

$\square \quad$ This is a phenomenon that cannot be explained with the shell model.

$\square \quad$ When it releases an electron, it has reached the noble gas configuration, i.e. its outermost shell is fully occupied.

$\square \quad$ An electron on the innermost shell is released very easily, since there are only 11 protons in the nucleus.

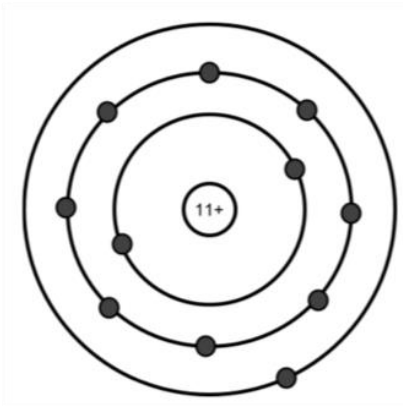

Figure 6. Test task on the topic shell model. (The question was originally given in German language.)

Except a few (527 out of a total of 530) all respondents answered the question (99.4\% validity). The correctness of the answer is $93 \%(\mathrm{~N}=490)$. Accordingly, it can be assumed that the shell is a well-known concept.

For the tasks of classifying elements into the corresponding groups such as metals and halogens, a multiple-choice format was chosen as well. In this section, the respondents have to tick which elements belong to the respective group (see Figure 7). Overall, the questions address groups of substances being of central importance in school lessons. These are introduced, for example, in the curriculum of Lower Saxony from grade 7 onwards and are more in depth in the following years.

Compared to the first task about the shell model, the validity of the two tasks is approximately the same (metals $99.1 \%, \mathrm{~N}=525$ and halogens $98.3 \%, \mathrm{~N}=521$ ). However, with regard to the correctness of the answers, a clearly different picture emerges. For example, $68.6 \%$ of the respondents were able to make the correct choice of elements for the main group metals. For halogens, the correctness of the choice is $56.4 \%$. It is astonishing that despite the regular repetition of these groups of elements in school lessons, the correct selection is about $2 / 3$ or $1 / 2$, respectively. Correspondingly, in parts, a well-founded knowledge is available, but it can't be assumed that prospective students have a holistic picture of which elements belong to this group when using terms such as halogens.

\section{Which of these element(s) belong(s) to the group of halogens?}

$\begin{array}{llll}\square & \text { Florine } & \square & \text { Chlorine } \\ \square & \text { Boron } & \square & \text { Iodine } \\ \square & \text { Argon } & & \end{array}$

$\square \quad$ Argon

\section{Which of the following elements are metals?}

$\begin{array}{llll}\square & \text { Magnesium } & \square & \text { Hydrogen (under standard conditions) } \\ \square & \text { Argon } & \square & \text { Lithium } \\ \square & \text { Carbon } & \square & \text { Aluminium }\end{array}$

$\square \quad$ Chlorine

Figure 7. Test questions concerning the elements of the groups of metals and halogens. (The question was originally given in German language.)

Finally, a task about the Lewis structure is presented. In this task, the respondents have to draw the Lewis structure of five different molecules (see Figure 8).

\section{Draw the Lewis formula/valence formula including non-binding electron pairs for the following molecules: $\mathrm{N}_{2}, \mathrm{CO}_{2}, \mathrm{H}_{2} \mathrm{O}, \mathrm{CH}_{4}, \mathrm{SO}_{4}{ }^{2-}$}

\section{Example: $\quad|\underline{\overline{\mathrm{Br}}}-\overline{\mathrm{Br}}|$}

Figure 8. Test questions on the topic Lewis structure. (The question was originally given in German language.)

The total validity of this task is $91.5 \%(\mathrm{~N}=485)$. Out of 485 respondents, $15.5 \%(\mathrm{~N}=75)$ solved the task entirely correct. At this point it should be noted that the complexity, an increased expenditure of time as well as knowledge from the upper secondary school were queried. Nevertheless, there were serious errors and inaccuracies in the drawings of the individual persons (see Figure 9). Above all, there were problems with the consistent drawing of the electron pairs especially considering the electron octet as well as the maximum numbers of electrons per specific element. This phenomenon can be observed across all subtasks regardless of the basic and advanced level in previous chemical education. 
a) School: Basic level Prospective degree: Chemistry majo School: Advanced level School: Advanced level $\underline{N}=\underline{N}$ Prospective degrt

School: Advanced level
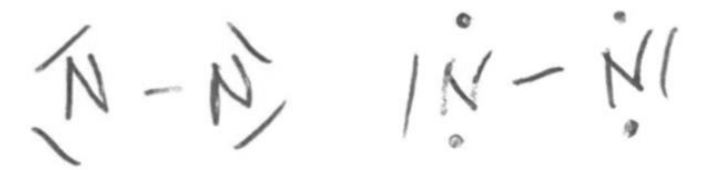

b) School: Up to grade 10 Prospective degree: Chemistry majo<smiles>COS(=O)(=O)O</smiles>

School: Advanced level

School: Advanced level

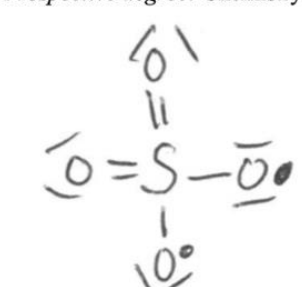

$$
\left.\hat{\nu}=0={ }^{\ominus} \stackrel{\theta}{\theta}=0=0\right\rangle
$$

$\underline{\text { O }}$

Figure 9. Sample drawings of the respondents. a) Answers of persons with a basic as well as with advanced level of requirements in the school subject chemistry for the molecule $N_{2}$. b) Answers of respondents with little experience in chemistry (up to grade 10) as well as with advanced level of requirements from school on the sulfate molecular ion $\left(\mathrm{SO}_{4}{ }^{2-}\right)$.

As a result, it can be stated that the use of the Lewis notation and its underlying concepts is difficult to understand and apply for many respondents. Accordingly, there is an increased need to catch up so that more advanced concepts, such as establishment of reaction mechanisms, can be developed and applied.

\section{Conclusion}

In summary, it can be concluded that prospective students with a good average Abitur grade are not very likely to show a better performance in chemical knowledge than persons with a lower average Abitur grade. Therefore, relying only on the average Abitur grade as an entrance selection criterion for higher education is not recommendable, because it just partly reflects a college readiness (Rindermann \& Oubaid, 1999). Similar results were already identified for college readiness in middle school by the study of Gaertner and McClarty (2015). They found that the

[...] achievement explains more variance in college readiness than any other factor at $17.1 \%$. That said, motivation and behaviour-independent of achievement-explain substantial variation in college readiness at $15.3 \%$ and $14.1 \%$, respectively. Together, these two factors explain more variation in college readiness $(29.4 \%)$ than achievement, [...]. (Gaertner \& McClarty, 2015, p. 25)

Furthermore, the test instrument shows that in the last four years, there has been no general tendency for a decrease in the content-specific knowledge of prospective students in chemistry major (B.Sc.), chemistry with teaching profession (B.A.), materials science (B.Sc.), biochemistry (B.Sc.), biology (B.Sc.) as well as a few other natural science programmes (B.Sc.) at the University of Göttingen. Only in 3 of 34 tasks a significant difference between the years can be found. Therefore, at least in the subject of chemistry, statements about the decrease of the contentspecific knowledge cannot be observed in our data. Rather, it can be seen that over all the years surveyed, certain tasks can be answered considerably better than others even if they are of comparable complexity in difficulty. Consequently, basic concepts in chemistry from schooldays cannot be taken for granted in a course of study.

Analyzing the content-specific characteristic of the college readiness and the average Abitur grade over the years, it can be stated that both approximately remain steady within the presented study. Hence, it can be derived that these two characteristics (cognitive and content-specific) - even though assumed to be the most important factors for a college readiness/academic success (Konegen-Grenier, 2002; Sorge et al., 2016) - are not the decisive factors for the (subjectively) perceived deterioration in the college readiness. Other factors, such as personal or social characteristics seem to be the key to determining college readiness.

\section{Limitations}

Concerning the scoring of individual tasks, two points should be taken into account. First, a task had been only assessed as correct if all parts of the tasks were correct, so no partial credits were given. Second, there was no distinguishing between level of difficulty while assessing a task. Therefore, for each task, just one point has been awarded for fulfilling the task completely correct. This strict analysis has been applied because the test reflects the content-specific knowledge required of freshmen and tests basic knowledge related to the curricula of schools.

\section{Recommendations to foster college readiness}

This study shows that about half of the total score of the content-specific knowledge test was achieved. This value should be questioned, since the test asked for the chemical knowledge required in higher education. Accordingly, it is important to ensure a proper training to improve content-specific knowledge in advance before entering university and, moreover, to promote and more focus it during their study at a university. The following options would be conceivable in order to support the college readiness, especially in cognitive and content-specific characteristics: 
- Establish preparatory courses in chemistry field (cf. Wolf, 2018).

- Professionalizing teaching assistants (called "Tutor" in German) could be beneficial for freshmen as well, because they provide the link between the freshman and the lecturer. Therefore, teaching assistant courses, where advanced chemistry students learn how to interact with freshmen according to their needs and using student-centered methods while teaching, are playing a key role. (Kröpke, 2015)

- Innovative teaching methods (concerning technology as well as pedagogy) should be used from the first semesters on and should be continuously adapted to the needs and abilities of new generations to put the students into the center of teaching and learning (Shaker \& Plater, 2016). Moreover, "Mlectures, small-group learning, and project-based learning all have positive associations with achievement provided they balance teacher-centered with student-centered instructional elements." (Schneider \& Preckel, 2017, p. 596)

In order to pursue a holistic concept of college readiness, further points should be taken into consideration, since the average Abitur grade and the content-specific knowledge are not the only factors for college readiness. Therefore, according to Sorge et al (2016), social and personal characteristics (both part of the study capacity) as well as study/general living conditions and behaviour of studying should also be taken into account. Thus, for a successful transition from secondary school to higher education, different factors could be considered:

- Instead of just taken the average Abitur grade into account as an access criterion for higher education and a college readiness, a specific-content knowledge, personality or self-efficacy test are advisable (cf. Dalgety \& Coll, 2006; Rindermann \& Oubaid, 1999). The latter is underlined by Dalgetva, Collb, who show in their work that "[t]here is evidence [...] that the influence of student self-efficacy on enrolment choices is stronger than that of attitude-toward-chemistry." (Dalgety \& Coll, 2006, p. 325)

- Schools and higher education institutions should make the necessary interventions to prevent prospective students from becoming dropouts in the further course of their studies due to excessive demands (cf. Heublein et al., 2017), because "[...] a lack of attention to academic behaviours causes problems for many first-year students, regardless of whether they possess the requisite content knowledge and key cognitive strategies." (Conley, 2011, p. 8) Interventions to target a culture shock and to create a common ground for a college readiness could be:

- Provide information days/internships at higher education institutions for prospective students (for example on study/general living conditions, study behaviour to "[...] help $[\ldots]$ students understand how to interact with professors and peers in college and how to navigate college as a social system and learning environment." (Conley, 2011, p. 1)

- Offer individual consultation (college instructor/mentoring programme), because they are "[...] more likely to emphasize a series of key thinking skills that students, for the most part, do not develop extensively in high school." (Conley, 2011, p. 2)

- Promotion of college readiness in the middle school. Therefore, the complex system of college readiness is addressed to pupils at an early stage. Intervention measures can be identified and initiated by educators accordingly. In particular, the behaviour and motivation of students can be specifically encouraged. (Gaertner \& McClarty, 2015)

- Establishment of counsellors' service in school to support the college readiness The involvement of school counsellors can "[...] minimize some of the negative influence of risk factors (e.g., poverty, high mobility rates, limited English proficiency) on school connectedness and, consequently, student success in both academic and non-academic areas." (Lapan et al., 2014, p. 311) Eventually, a personal relationship can be fostered and a sense of belonging to the school can be established. (Lapan et al., 2014, 2017)

- Opportunities to participate in higher education courses for young adults from the middle or upper school onwards. The authors Hooker and Brand describe that "[y]outh need early opportunities to complete college-level work, navigate college campuses, and understand how the structures, opportunities, and demands of higher education differ from those of high school." (Hooker \& Brand, 2010, p. 78) Hence, the pupil gain experience in higher education systems and can develop ideas for their own career path and eventually promote their college readiness.

Even though college readiness must be considered holistically and with regard to several factors, a basic content-specific prior knowledge is still an important predictor of college readiness and subsequently of an academic success. The aim of this study was therefore to investigate this content-specific prior knowledge in a longitudinal study within four years. In particular, it was analyzed whether a change in the content-specific knowledge occurs and thus indirectly influences college readiness. Such an influence could not be determined, since no significant drop in performance was observed during the period, but general strengths as well as deficits became apparent in content-specific chemical knowledge.

Disclosure Statement

The author report no conflict of interest. 


\section{References}

Bosse, E., Schultes, K., \& Trautwein, C. (2013). Studierfähigkeit als individuelle und institutionelle Herausforderung [College readiness as an individual and institutional challenge]. In D. Lenzen \& H. Fischer (Eds.), Change: Hochschule der Zukunft. Campus Innovation 2013. Konferenztag Studium und Lehre (Vol. 3, pp. 37-42). Universitätskolleg-Schriften. Retrieved from https://www.universitaetskolleg.unihamburg.de/de/publikationen/uk-schriften-003.pdf

Busker, M. (2010). Entwicklung einer adressatenorientierten Übungskonzeption im Übergang Schule - Universität auf Basis empirischer Analysen von Studieneingangsvoraussetzungen im Fach Chemie [Development of an addressee-related exercise concept in the transition from school to university on the basis of empirical analyzes of study entry requirements in the subject chemistry] (I. Parchmann, C. Hößle, M. Komorek, \& K. Wloka (eds.)). Der Andere Verlag.

Busker, M., Klostermann, M., Herzog, S., Huber, A., \& Parchmann, I. (2011). Nicht nur Schulwissen auffrischen: Vorkurse in Chemie [Not just refreshing school knowledge: Pre-courses in Chemistry]. Nacbricbten aus der Chemie, 59(6), 684-687.

Busker, M., Wickleder, M., \& Parchmann, I. (2010). Eingangsvoraussetzungen von Studienanfängern im Fach Chemie: Welches Vorwissen und welche Interessen zeigen Studierende? [Entrance requirements for first-year students in chemistry: What prior knowledge and interests do students have?]. CHEMKON, 17(4), 163-168. https://doi.org/10.1002/ckon.201010134

Conley, D. T. (2011). Redefining College Readiness (Volume 5). Eugene, OR: Educational Policy Improvement Center.

Conley, D. T. (2014). New Conceptions of College and Career Ready: A Profile Approach to Admission. Journal of College Admission, 223, 12-23.

Conley, D. T., \& French, E. M. (2014). Student Ownership of Learning as a Key Component of College Readiness. American Behavioral Scientist, 58(8), 1018-1034. https://doi.org/10.1177/0002764213515232

Dalgety, J., \& Coll, R. K. (2006). The influence of first-year chemistry students' learning experiences on their educational choices 1. Assessment \& Evaluation in Higher Education, 31(3), 303-328. choices 1. Assessment \& Evalud
https://doi.org/10.1080/02602930500352931

Eilks, I. (2007). Neue Wege zum Teilchenkonzept - Wie man Basiskonzepte forschungs- und praxisorientiert entwickeln kann [New ways to the concept of matter - How to develop basic concepts in a research- and practice-oriented way]. Naturwissenschaften im Unterricht Chemie, 18(100/101), 23-27.

Eilks, I., \& Möllering, J. (2001). Neue Wege zu einem fächerübergreifenden Verständnis des Teilchenkonzepts [New ways towards an inter-disciplinary understanding of the concept of matter]. Der Mathematische und Natumvissenschaftliche Unterricht, 54(4), 240-247.

Fokken, S. (2016). Bekommen Schuiler wirklich immer bessere Noten? [Do students indeed get continuously better grades?]. SPIEGEL ONLINE. Retrieved from https://www.spiegel.de/lebenundlernen/schule/abi-noten-imvergleich-gibt-es-eine-inflation-guter-zensuren-a-1125528.html

Freyer, K. (2013). Zum Einfluss von Studieneingangsvoraussetzungen auf den Studienerfolg Erstsemesterstudierender im Fach Chemie Influence of study entry requirements on the academic success of first-year students in chemistry]. Universität Duisburg-Essen.

Gaertner, M. N., \& McClarty, K. L. (2015). Performance, Perseverance, and the Full Picture of College Readiness. Educational Measurement: Issues and Practice, 34(2), 20-33.

Halsey, A. H. (1993). Trends in Access and Equity in Higher Education: Britain in International Perspective. Oxford Review of Education, 19(2), 129-140.

Heldmann, W. (1984). Studierfähigkeit - Ergebnis einer Umfrage [College readiness - survey results]. Schwartz.
Heublein, U., Ebert, J., Hutzsch, C., Isleib, S., König, R., Richter, J., \& Woisch, A. (2017). Zwischen Studienerwartungen und Studienwirklichkeit - Ursachen des Studienabbruchs, beruflicher Verbleib der Studienabbrecherinnen und Studienabbrecher und Entwicklung der Studienabbruchquote an deutschen Hochschulen [Between expectations and reality of studies - causes of university dropout, occupational destination of dropouts as well as development of the dropout rate at German universities].

Heublein, U., \& Schmelzer, R. (2018). Die Entwicklung der Studienabbruchquoten an den deutschen Hocbscbulen. Berechnungen auf Basis des Absolventenjabrgangs 2016 [The development of dropout rates at German universities. Analysis based on the graduating class of 2016]. DZHW-Projektbericht. Retrieved from https://www.dzhw.eu/pdf/21/studienabbruchquoten absolventen 2016.pdf

Heublein, U., Schmelzer, R., Sommer, D., \& Spangenberg, H. (2002). Studienabbrucbstudie 2002. Die Studienabbrecherquoten in den Fächergruppen und Studienbereichen der Universitäten und Facbhochschulen [Study on university dropouts 2002: Dropout rates in subject groups and fields of study at universities and universities of applied sciences].

Hooker, S., \& Brand, B. (2010). College knowledge: A critical component of college and career readiness. New Directions for Youth Development, 2010(127), 75-85. https://doi.org/10.1002/yd.364

Kazemzadeh, F., Minks, K.-H., \& Nigmann, R.-R. (1987). "Studierfähigkeit"- eine Untersucbung des Übergangs vom Gymnasium zur Universität [ "College readiness" - an analysis of the transition from high school to university]. HIS.

Klein, H.-P. (2019). Abitur und Bachelor für alle - wie ein Land seine Zukunft verspielt [Abitur and Bachelor for everybody - how a country is gambling away its future]. zu Klampen Verlag.

Konegen-Grenier, C. (2002). Studierfäbigkeit und Hocbschulrugang Hocbscbulrugang [College readiness and entrance qualification to higher education]. Deutscher Instituts-Verlag $\mathrm{GmbH}$.

Kröpke, H. (2015). Tutoren erfolgreich im Einsat: Ein praxisorientierter Leiffaden für Tutoren und Tutorentrainer [Teaching assistant successfully in action: a practical guide for teaching assistant and teaching assistant trainers]. Barbara Budrich.

Lapan, R. T., Poynton, T., Marcotte, A., Marland, J., \& Milam, C. M. (2017). College and Career Readiness Counseling Support Scales. Journal of Counseling \& Development, 95(1), 77-86. https://doi.org/10.1002/icad.12119

Lapan, R. T., Wells, R., Petersen, J., \& McCann, L. A. (2014). Stand Tall to Protect Students: School Counselors Strengthening School Connectedness. Journal of Counseling \& Development, 92(3), 304-315. https://doi.org/10.1002/j.1556-6676.2014.00158.x

McGrath, C. H., Henham, M. L., Corbett, A., Durazzi, N., Frearson, M., Janta, B., Kamphuis, B. W., Brankovic, N., Guerin, B., Manville, C., \& Schweppenstedde, D. (2014). Higber Education Entrance Qualifications and Exams in Europe: A Comparison. European Union: Brussels.

Nida-Rümelin, J. (2014). Der Akademisierungswahn - Zur Krise beruflicher und akademischer Bildung [The academic mania - crisis of vocational and academic education]. Edition Körber-Stiftung.

Rindermann, H., \& Oubaid, V. (1999). Auswahl von Studienanfängern durch Universitäten - Kriterien, Verfahren und Prognostizierbarkeit des Studienerfolgs [Selection of first-year students by universities - criteria, procedures and predictability of academic success]. Zeitschrift für Differentielle und Diagnostische Psychologie, 20(3), 172-191 https://doi.org/https://doi.org/10.1024/0170-1789.20.3.172

Schneider, M., \& Preckel, F. (2017). Variables associated with achievement in higher education: A systematic review of meta-analyses. Psychological Bulletin, 143(6), 565-600. https://doi.org/10.1037/bul0000098

Schuler, H. (2006). Noten als Prädiktoren von Studien- und Berufserfolg [Grades as predictors of academic and career success]. In D. H. Rost (Ed.), Handwörterbuch Pädagogische Psychologie (3rd ed., pp. 535-541). Beltz Verlag.

Sekretariat der Ständigen Konferenz der Kultusminister der Länder in der Bundesrepublik Deutschland. (2006). Abiturnoten im Ländervergleich [Abitur grades in national comparison]. Retrieved from https:/ www.kmk.org/dokumentation-statistik/statistik/schulstatistik/abiturnoten.html

Shaker, G. G., \& Plater, W. M. (2016). The Global Public Good: Students, Higher Education, and Communities of Good. Higher Learning Research Communications, 6(2), 1-10. https://doi.org/10.18870/hlrc.v6i2.332 
Shettle, C., Roey, S., Mordica, J., Perkins, R., Nord, C., Teodorovic, J., Brown, J., Lyons, M., Averett, C., Kastberg, D. (2007). The Nation's Report Card: America's High School Graduates (NCES 2007-467). U.S. Department of Education, National Center for Education Statistics. Washington, D.C.: U.S. Government Printing Office. Retrieved from https://nces.ed.gov/nationsreportcard/pdf/studies/2007467.pdf

Sorge, S., Petersen, S., \& Neumann, K. (2016). Die Bedeutung der Studierfäbigkeit für den Studienerfolg im 1. Semester in Physile [The relevance of the study capacity for success in introductory physics courses]. Zeitschrift für Didaktik der [The relevance of the study capacity for success in introductory physics courses].

Thiel, F., Veit, S., Blüthmann, I., Lepa, S., \& Ficzko, M. (2008). Ergebnisse der Befragung der Studierenden in den Bachelorstudiengängen an der Freien Universitä Berlin [Survey results of bachelor program students at the Freie Universität Berlin]. Berlin.

Trapmann, S., Hell, B., Weigand, S., \& Schuler, H. (2007). Die Validität von Schulnoten zur Vorhersage des Studienerfolgs - Eine Metaanalyse [The validity of school grades predicting academic success - A meta-analysis]. Zeitschrift für Pädagogische Psychologie, 21(1), 11-27. https://doi.org/10.1024/1010-0652.21.1.11

United Nations Economic and Social Council. (2019). Special edition: progress towards the Sustainable Development Goals - Report of the Secretary-General. https://undocs.org/E/2019/68

Wolf, K. (2018). Chemie im Übergang zavischen Scbule und Hocbscbule [Chemistry in the transition between school and university]. Georg-August-Universität Göttingen.

Wolter, A., \& Kerst, C. (2015). The 'academization' of the German qualification system - Recent developments in the relationships between vocational training and higher education in Germany. Research in Comparative and International Education, 10(4), 510-524. https://doi.org/10.1177/1745499915612188

Ziomek, R. L., \& Svec, J. C. (1995). High School Grades and Achievement: Evidence of Grade Inflation. In ACT Research Report Series (November Issue). 